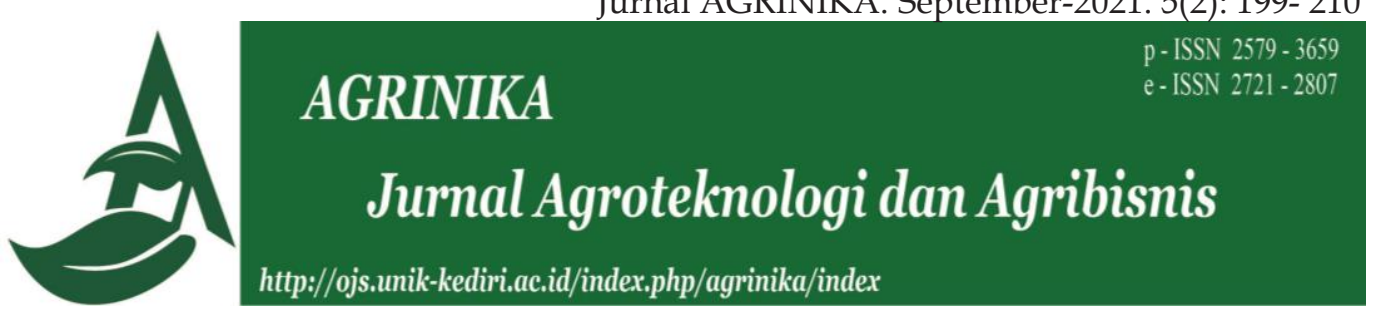

\title{
Pengembangan Usaha Agroindustri Noni (mengkudu) dengan Pendekatan Decission Support System
}

\author{
Andika Putra Setiawan ${ }^{{ }^{*}}$, Abdoel Djamali ${ }^{1}$, Danang Kumara Hadi ${ }^{1}$, Risa Martha ${ }^{1}$, \\ Satriya Bayu Aji ${ }^{1}$ \\ ${ }^{1}$ Fakultas Pertanian, Universitas Muhammadiyah Jemberi, Jember, Indonesia \\ *Korespondensi: andikaputra@unmuhjember.ac.id
}

Diterima 19 Agustus 2021/ Direvisi 13 September 2021/ Disetujui 22 September 2021

\begin{abstract}
ABSTRAK
Mengkudu (Morinda citrifolia) adalah tanaman obat yang banyak peminatnya dari kalangan pengusaha industri obat tradisional dan peneliti diberbagai negara. Penelitian ini bertujuan untuk merancang pengembangan usaha agroindustri UD. ZAM untuk meningkatkan daya saing. Rancangan penelitian ini adalah deskriptif menggunakan metode expert system. Teknik analisis menggunakan software DSS UMKM version 2.0 dengan model analisis aspek hukum, aspek pemasaran, aspek produksi, aspek manajemen dan sumber daya manusia, aspek lingkungan, dan aspek keuangan. Hasil penelitian yang diperoleh adalah UD. ZAM telah memiliki kelengkapan legalisasi usaha Tanda Daftar Perusahaan (TDP) 13.07.5.47.25386, Surat Izin Usaha Perdagangan (SIUP) 503/0087/411/2015, Nomor Pokok Wajib Pajak (NPWP) 72.691.633.1-626.000, Izin Usaha Industri (IUI) 503/3212/411/2015, dan P-IRT NO2133509103570-21. Pemasaran produk noni selama ini berorientasi ekspor yang memiliki kelebihan kepastian pasar sehingga layak untuk dikembangkan, pada aspek kinerja produksi menunjukkan tingkat kelayakan rendah, aspek sumber daya manusia sistem upah yang diberikan oleh UD. ZAM standart Upah Minimum Regional (UMR) dan memberi lapangan pekerjaan pada masyarakat pedesaan, pada aspek kinerja lingkungan tingkat kelayakan tinggi, karena selama ini mudah untuk mendapatkan bahan baku, pada aspek keuangan seperti asumsi tingkat bunga sebesar $15 \%$, break event point (BEP) kuantitas 25.833.87 maupun (BEP) penjualan 261.397.03,77, benefit coast ratio (BCR) 2,35, payback period 1,23, net present value (NPV) 18.066.137.185,78, probability index (PI) 11,28, dan internal rate of return(IRR) 56,44 maka layak dikembangkan lebih lanjut.
\end{abstract}

Kata kunci : Agroindustri Mengkudu; Decision Support System (DSS).

\section{ABSTRACT}

Noni or pace (Morinda citrifolia) is a medicinal plant with much interest from entrepreneurs in the traditional medicine industry and researchers in various countries. This study aimed to design the development of an agro-industry business (UD. ZAM) to increase competitiveness. The design of this research was descriptive using the expert system method. The analysis technique employed the MSME DSS software version 2.0 with a legal, marketing, management, human resources, environmental, and financial analysis model to design a Decision Support System. The results obtained were that UD. ZAM already had complete business legalization, such as Company Registration Certificate (TDP) 13.07.5.47.25386, Trading Business License (SIUP) 503/0087/411/2015, Taxpayer Identification Number (NPWP) 72.691.633.1-626.000, and Permit Industrial Business (IUI) 503/3212/411/2015, and P-IRT NO2133509103570-21. Therefore, with the license certificate, UD. ZAM was legal. In the marketing of noni products so far, it is export-oriented, which has advantages so that it can be developed. 
In terms of production performance, it shows the required production process and aspects of human resources provided by UD. ZAM standard regional minimum wage (UMR) and employment in rural areas, in a high feasibility environment, because it was easy to obtain materials and in financial aspects such as the assumption of an interest rate of $15 \%$, break event point (BEP) quantity $25,833.87$ and (BEP) sales 261.397.03.77, benefit coast ratio (BCR) 2.35, payback period 1.23, net present value (NPV) 18.066.137.185.78, probability index (PI) 11, 28, and internal rate of return (IRR) 56.44.

Keywords: Noni Agroindustry; Decision Support System (DSS).

\section{PENDAHULUAN}

Indonesia adalah negara agraris salah satu sektor produksi terbesar dari tanaman Biofarmaka antara lain jahe, kunyit, kapulaga, laos / lengkuas, kencur, temulawak, lidah buaya, mahkota dewa, mengkudu / pace, temu ireng, temu kunci, sambiloto, kejibeling, dringo. Jumlah produksi tanaman mengkudu pada tahun 2017 sebanyak $4.629 .225 \mathrm{~kg}$ dan 2018 sebesar $5.741 .585 \mathrm{~kg}$ hal ini terjadi peningkatan hasil panen 24,03\% (Badan Pusat Statistik, 2018).

Morinda citrifolia L sejak dahulu telah digunakan sebagai makanan dan obat tradisional oleh masyarakat suku polinesia (Motshakeri M dan Ghazali, 2015). Buah mengkudu terdapat kandungan antioksidan dan polifenol yang sangat baik sehingga bermanfaat untuk penangkal radikal bebas (Sina $\mathrm{H}$, Dramane G, Tchekounou P et al, 2020). Selain itu senyawa fitokimia seperti antrakuinon, alkaloid, tanin, flavonoid, steroid, triterpenoid, saponin, dan fenolik (Sogandi dan Rabima, 2019). Maka cocok untuk dijadikan minuman fungsional yang berguna bagi Kesehatan tubuh.

Hingga kini pemanfaatan buah mengkudu masih terbatas. Salah satu faktor penyebab Indonesia kalah bersaing dengan negara tetangga. $\mathrm{Di}$ era pandemi pada bulan Januari - Juli 2020 nilai ekspor produk herbal Indonesia 5.69 juta US Dollar telah terjadi penurunan $12.60 \%$ dibandingkan dengan tahun 2019 sebesar 6.51 juta US Dollar (Kementerian Perdagangan Republik Indonesia, 2020). Namun konsumsi obat tradisional masyarakat Indonesia turun setelah adanya program (JKN) Jaminan Kesehatan Nasional, dengan terbitnya program tersebut obat kimia mudah didapatkan sebagai pengganti obat tradisional (Diniarti I dan Iljanto S, 2017).

UD. ZAM adalah salah satu Usaha Mikro Kecil Menengah (UMKM) yang berada di Kecamatan Gumukmas Kabupaten Jember saat ini telah berhasil memproduksi cairan buah mengkudu yang bernilai ekonomis tinggi. Bahkan telah ekspor ke China, Singapura, dan Perancis. Peluang usaha obat herbal di Indonesia tentu besar di era pandemi, karena tren gaya hidup Back To Nature yang marak di negara maju kini sudah mulai masuk di Indonesia yang turut andil dalam penggunaan obat tradisional di semua kalangan masyarakat (Diniarti I dan Iljanto S, 2017). Sebagai produsen minuman herbal harus berwawasan yang luas tentang manajemen dan teknologi yang tepat supaya mampu bersaing di pasar.

Potensi Indonesia tentang obat tradisional sangat besar, jika tidak di manfaatkan akan kalah bersaing oleh produk impor. Karena ketertarikan masyarakat terhadap obat tradisional semakin tinggi (WHO, 2013). Pemerintah harus bekerjasama ke berbagai instansi baik nergi maupun swasta untuk pengembangan teknologi dan sumber daya manusia. Supaya 
mampu bersaing dalam bidang pengolahan tanaman herbal.

Banyak hal yang perlu diterapkan untuk pengembangan daya saing UD. ZAM dan pentingnya proses pengambilan keputusan di setiap aktivitas bisnis dalam suatu perusahaan. Karena pada dasarnya pemberdayaan UMKM adalah langkah strategis dalam peningkatan perekonomian masyarakat (Nurdiyanto H dan Meilia H, 2016).

\section{BAHAN DAN METODE}

Penelitian ini menggunakan metode deskriptif dilakukan pengamatan kemudian dideskripsikan suatu keadaan secara ilmiah (Masyhud, 2011). Bertujuan untuk mencatat, menganaisis, dan menginterprestasi suatu kondisi yang terjadi pada aspek hukum, pemasaran, produksi, manajemen sumber daya manusia, lingkungan, dan keuangan di UD. ZAM.

Metode expert system adalah metode analisis untuk sebuah masalah pengambilan keputusan dan alternatif dengan cara interview pada pakar dan praktisi sesuai dengan bidangnya (Marimin, 2005).

Dalam pembentukan expert system diperlukan beberapa pakar di bidang yang sama dan rekayasa sistem sebagai perancang. Pakar yang dilibatkan dapat dibagi dalam empat kelompok yaitu:

a. Pakar yang pendidikan formal S2/S3 pada bidang yang dikaji.

b. Pakar yang berpengalaman pada bidang yang dikaji, tetapi pendidikan formal di bidang lain.

c. Pakar yang berpendidikan formal dan berpengalaman pada bidang yang dikaji.

d. Pakar yang berasal dari praktisi yang lebih didasarkan pada lama kerja dan kewenangan (dapat terdidik secara formal atau otodidak) di suatu posisi kegiatan teknik tertentu.

Penulis memilih pakar yang sesuai dengan bidang pengolahan pangan dan manajemen anatara lain Akhmad Muadi selaku owner UD. ZAM, Mokhamad Fatoni selaku dosen Teknologi Pangan, dan Sumadi sebagai akademis manajemen agribisnis.

\section{Tempat dan Waktu Penelitian}

Penelitian dilaksanakan di UD. ZAM Dusun Bagorejo, Kecamatan Gumukmas, Kabupaten Jember. Karena UMKM tersebut merupakan satusatunya pengolah cairn mengkudu yang sudah di ekspor. Dalam penelitian ini penentuan daerah penelitian digunakan purposive area yang berarti lokasi yang dipilih peneliti berdasarkan beberapa pertimbangan tertentu (Sugiyono, 2013).

\section{Prosedur Pengumpulan Data}

Metode pengumpulan yang digunakan yaitu interview dan dokumentasi.

\section{a. Wawancara}

Teknik pengumpulan data dua arah antara subjek dan obyek (Arikunto, 2010). wawancara tersebut agar diketahui fenomena atau keadaan di lokasi.

b. Dokumentasi

Dalam pelaksanakan dokumentasi, diselidiki benda-benda tertulis seperti buku, majalah, dokumen, arsip, peraturan-peraturan, notulen rapat, dan catatan harian (Arikunto, 2010). Dengan obyek utama UD. ZAM.

\section{Teknik Analisis}

Teknik analisis struktur dasar Decision Support System (DSS) yang dihubungkan pengambil keputusan. Struktur dasar DSS adalah interaksi pengambil keputusan dengan bantuan 
komputer. Perancangan Decision Support System dengan bantuan software DSS UMKM version 2.0, model analisis aspek hukum, pemasaran, produksi manajemen sumber daya manusia, lingkungan, dan keuangan.

Model Decision Support System telah berwujud satu paket pada software DSS UMKM version 2.0 karya Deputi Bidang Pengkajian Sumber daya UKMK hak paten tahun 2010, yaitu model tersistem dari aspek hukum, pemasaran, produksi, manajemen sumber daya manusia, lingkungan, dan keuangan.

\section{HASIL DAN PEMBAHASAN}

\section{Aspek Hukum}

Software DSS version 2.0 menunjukkan hasil analisis aspek hukum sebagai berikut:

Tabel 1. Hasil analisis aspek hukum

Nama Perusahaan/Koperasi
No. Badan Hukum
Tanggal Berdiri
Alamat Perusahaan/ Koperasi
Nomor Telpon
Faksimile
Alamat email
Nomor Pokok Wajib Pajak (NPWP)
Tanda Daftar Perusahaan (TDP)
Surat Izin Usaha Perdagangan (SIUP)
Nama pemilik perusahaan
1. Direktur
2. Dewan Komisaris
Bentuk badan hukum perusahaan
Lama perusahaan berdiri
Perusahaan memiliki cabang

Sumber: Output DSS Analisis Aspek Hukum

Output DSS yang terdapat pada aspek hukum bahwa UD. ZAM sudah punya nomor badan usaha dengan nomor 26, yang berdiri sejak 27 Desember 2014, selama ini sudah beroperasi selama kurang lebih 7 tahun, alamat di Jl. Tembokrejo 01 bagorejo Kecamatan Gumukmas Kabupaten Jember. Dari beberapa persyaratan pendirian usaha sudah dipenuhi seperti, Tanda Daftar Perusahaan (TDP) 13.07.5.47.25386, Surat Izin Usaha Perdagangan (SIUP) 503 / 0087 / 411 / 2015, Nomor Pokok Wajib Pajak (NPWP) 72.691.633.1-626.000, dan Izin Usaha Industri (IUI) 503 / 3212 / 411 / 2015, dan P-IRT NO : $2133509103570-$

\author{
UD.ZAM \\ 26 \\ 27 Desember 2014 \\ Jl. Tembokrejo 01 bagorejo, Kec. \\ Gumukmas, Kab. Jember \\ 081358016053
}

\author{
726916331626000 \\ 130754725386 \\ 503/0087/411/2015 \\ Akhmad Muadi \\ Akhmad Muadi \\ Siti Zulva \\ 3. Perusahaan perorangan \\ 6 tahun \\ Tidak
}

21. Maka UD. ZAM sudah legal dalam hukum.

Pengembangan usaha pada aspek hukum belum punya email perusahaan, jadi perlu ditambah dan pembuatan website. Supaya konsumen bisa tahu profil UD. ZAM, karena pada sekarang ini media sosial cenderung di manfaatkan oleh masyarakat. Dalam perizinan produk makanan dan minuman harus terdapat sertifikat halal yang di terbitkan oleh Majelis Ulama Indonesia (MUI) regional setempat dan nomor dari Badan Pengawas Obat dan Makanan (BPOM). Dengan adanya perizinan yang lengkap perusahaan akan dipercaya 
oleh konsumen, sehingga lebih mudah bersaing di pasar.

\section{Aspek Kinerja Marketing}

Kinerja marketing UD. ZAM dianalisis dengan skoring DSS dan diperoleh hasil output sebagai berikut:

Tabel 2. Analisis aspek marketing

\begin{tabular}{lcc}
\hline \multicolumn{1}{c}{ Uraian } & Skor & Ilustrasi Warna \\
\hline Produk & 14 & \\
Harga & 9 & \\
Distribusi & 11 & \\
Market Share & 7 & \\
Segmentasi dan & 6 & \\
positioning & & \\
Promosi & 11 & \\
Sumber: Output Skoring Kinerja Marketing DSS
\end{tabular}

Output skoring kinerja marketing di tunjukkan bahwa distribusi dan segmentasi positioning berada pada tingkat kelayakan tinggi yang berwarna hijau. Sedangkan poduk, harga, market share, dan promosi berada pada tingkat kelayakan sedang di tunjukkan dengan warna kuning. Berikut penyebab tingkat kelayakan:

a) Produk menunjukkan skor 14 yang artinya tingkat kelayakan sedang. Hal ini disebabkan cairan mengkudu adalah produk olahan tanpa bahan campuran dan aroma khas mengkudu tidak berkurang. Produk tersebut sudah diakui oleh sucufindo sehingga mampu bisa ekspor.

b) Harga menunjukkan skor 9 sehingga tingkat kelayakan sedang. Di sebabkan oleh tingkat harga jual produk sedang, karena harga sudah ditetapkan oleh buyers / tengkulak di Tiongkok sebagai pengepul cairan mengkudu.

c) Distribusi dijual ke buyers / tengkulak di tunjukkan skor 11 sehingga tingkat kelayakan tinggi. karena wilayah pemasaran luas sampai ke luar negeri dengan pengepul. Maka UD. ZAM berhasil ekspor ke Tiongkok, Jerman, Perancis, dan Singapura melalui pedagang besar tersebut. d) Market Share menunjukkan skor 7 dan tingkat kelayakan sedang. Karena pemasaran produk luas sampai ke luar negri dan posisi perusahaan dalam pasar Marketing Challage (menantang pasar).

e) Segmentasi Pasar menunjukkan skor 6 tingkat kelayakan tinggi. Karena segmentasi pasar perusahaan terpusat, dan penempatan pasar yang dituju fokus kepada pelanggan meskipun hanya beberapa negara yang telah membeli produk cairan buah mengkudu UD. ZAM yaitu Tiongkok, Jerman, Perancis, dan Singapura

f) Promosi menunjukkan skor 11 dan tingkat kelayakan sedang. Karena promosi yang digunakan hanya media cetak dan elektronik seperti radio dan pamflet. Biaya promosi yang dikeluarkan rata-rata pertahun sedang, intensitas promosi yang dilakukan perusahaan tinggi, dan dampak promosi bagi perusahaan yang dijalankan perusahaan sedang.

Pada aspek kinerja marketing perlu adanya pengembangan market share atau pangsa pasar, karena ujung tombak dari keberhasilan sebuah perusahaan. Perlu adanya peluasan pangsa pasar didalam negri, supaya 
tidak ada tekanan dari buyers bahkan penurunan harga oleh pengepul di Tiongkok karena selama ini terjadi penurunan yang awalnya di beli dengan harga Rp. 12.000 per liter kini menjadi Rp. 10.000 per liter. Jika dibiarkan akan timbul kerugian. Maka dengan adanya pelebaran pangsa pasar di dalam negri buyers tidak bermain harga, sehingga jadi saling menguntungkan.

\section{Aspek Kineria Produksi}

Kinerja aspek produksi UD. ZAM dianalisis dengan Skoring DSS diperoleh hasil berikut:

Tabel 3. Hasil analisis aspek produksi

\begin{tabular}{lcll}
\multicolumn{1}{c}{ Uraian } & Skor & Ilustrasi Warna \\
\hline Lokasi Usaha & 3 & \\
Fasilitas Produksi dan Alat & 2 & \\
Tenaga Kerja & 13 & \\
Teknologi Usaha & 7 & \\
Proses Produksi & 4 & \\
Kapasitas Produksi & 4 & \\
Sumber: Output Skoring Kinerja Produksi DSS &
\end{tabular}

Output skoring kinerja Produksi yaitu lokasi usaha dan tenaga kerja berada di tingkat kelayakan tinggi Sedangkan fasilitas produksi dan peralatan, teknologi, kapasitas produksi menunjukkan kelayakan sedang. Proses produksi tingkat kelayakan rendah. Penyebab tingkat kelayakan sebagai berikut:

a) Lokasi usaha dekat dengan sumber bahan baku di tunjukkan skor 3 tingkat kelayakan tinggi. Karena lokasi perusahaan mudah dijangkau sekitar $45 \mathrm{~km}$ dari pusat kota jember. Sehingga akses transportasi ke lokasi perusahaan mudah ditempuh.

b) Fasilitas produksi dan peralatan terdapat skor 2 tingkat kelayakan sedang. Hal ini disebabkan jumlah sarana prasarana seperti gedung, kendaraan, dan peralatan produksi sehari-hari masih tergolong sederhana.

c) Tenaga kerja berasal dari masyarakat sekitar pabrik, memiliki skor 13, dan tingkat kelayakan tinggi. Karena tenaga kerja sangat mudah didapatkan. Sehingga dengan berdirinya UD. ZAM pengangguran bisa berkurang. Gaji tenaga kerja sesuai dengan Upah Minimum Regional Kabupaten Jember (UMR). Pada saat ini upah minimum regional (UMR) Rp. 2.200.000.

d) Teknologi memiliki skor 7 tingkat kelayakan sedang. Karena padat teknologi seperti proses pencairan dan pengepresan tidak membutuhkan banyak karyawan namun pada proses sortasi, pencucian, dan pengeringan tetap membutuhkan tenaga kerja.

e) Kapasitas produksi menunjukkan skor 4 tingkat kelayakan sedang. Karena jumlah produksi yang dihasilkan perusahaan berkisar pada titik impas. Dalam proses produksi cairan buah mengkudu butuh biaya yang banyak dan waktu lama, maka perusahaan harus bisa mengatur perputaran uang dan sumber daya manusia agar bisa mendapatkan hasil diatas titik impas.

f) Proses produksi mendapatkan skor 4 tingkat kelayakan rendah. Karena produsksi melalui banyak tahapan mulai persiapan tanaman mengkudu, 
perawatan, pemanenan, sortasi, pencucian, pengeringan, pencairan, pengepresan, pasteurisasi, dan pengemasan. Waktu yang dibutuhkan untuk mendapatkan cairan buah mengkudu 3-5 bulan.

Pada aspek kinerja produksi perlu adanya pengembangan bagian proses produksi, karena warna ilustrasi proses produksi merah sehingga tingkat kelayakan rendah. Maka yang perlu diperbaiki oleh UD. ZAM adalah penyusunan Standart Operasional Prosedure (SOP) mulai pemilihan bahan baku hingga pengemasan dan memperbaharui peralatan yang modern.

6. Aspek Kinerja Manajemen dan Sumber Daya Manusia

Kinerja manajemen dan sumber daya manusia UD. ZAM dianalisis dengan Skoring DSS dan diperoleh hasil output sebagai berikut:

Tabel 4. Hasil analisis aspek MSDM

\begin{tabular}{lc|c}
\multicolumn{1}{c}{ Uraian } & Skor & Ilustrasi Warna \\
\hline Bentuk Organisasi & 5 & \\
Profil Usaha & 5 & \\
Konpensasi & 2 & \\
\hline
\end{tabular}

Sumber: Output Skoring Kinerja MSDM DSS

Output skoring kinerja manajemen dan sumber daya manusia DSS terdapat dua poin yang berada pada tingkat kelayakan tinggi yaitu bentuk organisasi dan profil usaha. Adapun penyebab tingkat kelayakan sebagai berikut:

a) Bentuk organisasi dapat skor 5 maka kelayakan tinggi. Karena perusahaan legalitas perusahaan lengkap seperti, Tanda Daftar Perusahaan (TDP) 13.07.5.47.25386, Surat Izin Usaha Perdagangan (SIUP) 503 / 0087 / 411 / 2015, Nomor Pokok Wajib Pajak (NPWP) 72.691.633.1-626.000, Izin Usaha Industri (IUI) 503 / 3212 / 411 / 2015, P-IRT NO.: 213350910357021. Adanya surat perizinan yang sah UD. ZAM dianggap legal.

b) Profil usaha ditunjukkan skor 5 maka tingkat kelayakan tinggi. Karena di skala usaha menengah pendapatan bersih lebih dari Rp. 200 Juta tidak termasuk tanah dan bangunan. Tempat usaha berdiri sendiri, bukan cabang dari perseroan, dan berbadan hukum yang sah. Sistem pengelola hanya keluarga dan karyawan yang berkompeten.

c) Kompensasi dapat skor 2 maka tingkat kelayakan sedang. Karena upah/gaji yang diberikan standart Upah Minimum Regionol (UMR) Kabupaten Jember.

Pengembangan usaha dalam aspek Manajemen Sumber Daya Manusia perlu diperbaiki terutama dalam kompensasi. Karena kompensasi adalah salah satu fungsi yang penting dalam manajemen Sumber Daya Manusia (MSDM) karena paling sensitif dalam hubungan kerja. Jika tingkat upah yang diberikan perusahaan tinggi dan karyawan merasa puas, maka akan timbul rasa semangat dalam bekerja.

\section{Aspek Kinerja Lingkungan}

Kinerja lingkungan UD. ZAM dianalisis dengan Skoring DSS diperoleh hasil output (Tabel 5). Output Skoring kinerja lingkungan DSS yaitu pada poin bahan baku tingkat kelayakan tinggi yang memiliki skor 13. 
Tabel 5. Hasil Analisis Aspek Lingkungan

\begin{tabular}{ccc}
\hline Uraian & Skor & Ilustrasi Warna \\
\hline Bahan Baku & 13 & \\
Tingkat Persaingan & 11 & \\
Sumber: Output Skoring Kinerja Lingkungan DSS &
\end{tabular}

Penyebab tingkat kelayakan sebagai berikut:

a) Bahan baku ditunjukkan skor 13 maka tingkat kelayakan tinggi. Karena ketersediaan bahan baku dari petani local. Buah mengkudu yang semula tidak memiliki nilai jual kini telah laku sebesar Rp. 2.000 per kg. Dengan berdirinya UD. ZAM perekonomian masyarakat dan petani juga semakin sejahtera.

b) Tingkat persaingan di tunjukkan oleh skor 11 maka tingkat kelayakan tinggi. Artinya jumlah pesaing pada industri sejenis disekitar perusahaan sangat sedikit bahkan tidak ada. Penghalang dalam industri tersebut rendah hal ini di sebabkan masih jarang yang produksi cairan buah mengkudu di Jawa Timur apalagi di Jember tentu belum ada.

Pada aspek kinerja lingkungan dapat disimpulkan bahwa UD. ZAM telah terbukti kinerjanya di aspek kinierja lingkungan tersebut di tingkat kelayakan tinggi dan perlu berkomitmen untuk terus berkembang.

\section{Aspek Keuangan}

Kinerja keuangan UD. ZAM dianalisis dengan Analisis Kelayakan Investasi DSS dan diperoleh hasil sebagai berikut:

Tabel 6. Hasil Analisis Aspek Keuangan

\begin{tabular}{ll}
\hline Asumsi Tingkat Bunga & $15 \%$ \\
Periode Waktu & 10 Tahun \\
Modal Awal & 1.757 .075 .000 \\
BEP Kuantitas & $25.833,87$ \\
BEP Penjualan & $261.397 .031,77$ \\
BCR & 2,35 \\
Payback Period & 1,23 \\
NPV & $18.066 .137 .185,78$ \\
PI & 11,28 \\
IRR & 56,44 \\
\hline
\end{tabular}

Sumber: Output Analisis Kelayakan Investasi DSS

Berdasarkan output analisis kelayakan investasi DSS diperoleh hasil analisis yang dijelaskan secara detail sebagai berikut:

a) Tingkat bunga setiap tahun sebesar $15 \%$. Persentase ini adalah landasan besaran diskonto nilai waktu uang atau landasan inflasi yang telah terjadi. Tingkat bunga tersebut lebih besar dari tingkat bunga bank pada umumnya, yaitu di bawah $15 \%$ (Otoritas Jasa Keuangan, 2021). b) Periode waktu untuk proyeksi selama 10 tahun yang telah dilakukan dengan software DSS UMKM dimana jumlah periode tepat sebagai proyeksi. Dalam rancangan pengembangan usaha akan dibatasi 5 tahun periode untuk mendapatkan hasil proyeksi yang realistis. Penelitian Bahari et al. (2021) juga memproyeksikan 5 tahun karena peralatan yang digunakan untuk 
produksi rata-rata memiliki umur ekonomis 5 tahun.

c) Modal awal sebesar $\mathrm{Rp}$ 1.757.075.000 adalah biaya investasi yang dikeluarkan oleh UD. ZAM. Biaya investasi dalam analisis adalah hasil dari landasan yang diambil dari laporan keuangan tahun terakhir terkait inventaris yang dimiliki. Kemudian dijadikan biaya awal investasi pada input software DSS UMKM sebagai dasar proyeksi kinerja keuangan pada masa yang akan datang. Modal awal tersebut tidak berbeda jauh dengan hasil penelitian lainnya seperti Cholilie (2018) yang menyatakan modal awal senilai milyaran rupiah.

d) Nilai BEP kuantitas sebesar $25.833,87$ yang artinya untuk diperoleh nilai kembali biaya total produksi (tidak untung dan tidak rugi) perusahaan harus jual produk sebanyak 25.833,87 liter dalam satu kali produksi selama 5-6 bulan per produksi. Dengan ini bahwa tingkat kelayakan kinerja keuangan yang dianalisis melalui BEP Kuantitas berada pada tingkat layak.

e) Nilai BEP Penjualan yang dimiliki sebesar 261.397.031,77 artinya untuk diperoleh titik impas Break Event Point (BEP) penjualan produk yang harus dijual perusahaan sampai pendapatan sebesar $\mathrm{Rp}$ 261.397.031,77 dalam satu kali produksi. Maka dengan ini ditunjukkan tingkat kelayakan kinerja keuangan yang dianalisis dengan Break Evebt Point (BEP) Penjulan berada pada tingkat layak.

f) BCR (Benefit Coast Ratio) adalah perbandingan antara NPV total dari benefit bersih terhadap total dari biaya bersih. Nilai sebesar 2,35, sehingga bahwa dari setiap rupiah yang dikeluarkan akan dihasilkan keuntungan Rp. 2,35. Karena nilai BCR UD. ZAM > 1, maka tingkat kelayakan kinerja keuangan yang dianalisis berada pada tingkat layak. Beberapa penelitian seperti Bahari et al. (2021), Cholilie (2018), Ibrahim dan Bakhtiar (2017) juga menggunakan kriteria net $\mathrm{B} / \mathrm{C}>1$ untuk menyatakan kelayakan suatu usaha.

g) Payback Period adalah waktu yang dibutuhkan atas investasi dihasilkan cash flow dapat ditutupi biaya investasi yang telah dikeluarkan. Nilai Payback Period pada UD. ZAM sebesar 1,23, artinya waktu dibutuhkan untuk biaya investasi yang telah dikeluarkan selama 1 tahun. Hal ini lebih singkat jika dibandingkan dengan proyeksi selama 5 tahun. Maka tingkat kelayakan kinerja keuangan yang dianalisis menggunakan Payback Period pada tingkat layak. Hasil tersebut sama dengan hasil Bahari et al. (2021), Cholilie (2018) yang kriteria kelayakan usaha berdasarkan nilai PP dibandingkan dengan umur usaha dan harus lebih kecil.

h) NPV (Net Present Value) pengukuran berapa nilai yang dihasilkan saat ini seandainya penanaman investasi. NPV juga perbedaan di antara nilai pasar investasi dan biaya yang di keluarkan. Nilai NPV yang terdapat pada UD. ZAM sebesar 18.066.137.185,78, yang artinya berdasarkan investasi yang telah dilakukan, nilai yang dapat dihasilkan saat ini sebesar Rp 18.066.137.185,78. Dengan ini NPV (Net Present Value) ditunjukkan nilai positif. Maka kelayakan kinerja keuangan NPV berada pada tingkat layak, karena $>0$. Menurut hasil 
penelitian Bahari et al. (2021), Cholilie (2018), Ibrahim dan Bakhtiar (2017) NPV harus bernilai positif untuk dinyatakan layak.

i) PI (Probability Index) adalah perbandingan antara nilai Cash Flow dengan biaya investasi yang dikeluarkan. Nilai PI sebasar 11,28, sehingga artinya kemampuan Cash Flow investasi adalah 11,28 kali. Maka tingkat kelayakan kinerja keuangan dianalisis dengan Profitability Index berada pada tingkat layak, karena jauh dari diatas standart minimal $>1$. Hasil penelitian Cholilie (2018) juga menghasilkan PI $>1$ sehingga pabrik layak direalisasikan.

j) IRR (Internal Rate of Return) adalah tingkat diskonto sebagai penyebab NPV investasi sama dengan 0 . IRR dapat dianggap sebagai tingkat keuntungan atas investasi bersih dari suatu usaha. Nilai IRR yang dimiliki oleh UD. ZAM sebesar 56,44, yang artinya nilai bersih sekarang dapat jadi 0 apabila tingkat diskonto (suku bunga) sebesar 56,44 \%. Sehingga analisis kinerja keuanga IRR (Internal Rate of Return) yang terdapat pada UD. ZAM berada pada tingkat layak. Menurut hasil penelitian Bahari et al. (2021) dan Sholihin et al. (2016) kegiatan usaha layak untuk dijalankan apabila nilai IRR nya lebih besar dari bunga bank yang berlaku.

\section{KESIMPULAN}

Berdasarkan pembahasan

Pengembangan Usaha Agroindustri Noni dengan Pendekatan Decission Support System (DSS), dapat disimpulkan bahwa:

a) Pengembangan Pada Aspek Hukum kelengkapan legalisasi seperti Tanda Daftar Perusahaan (TDP), Surat Izin
Usaha Perdagangan (SIUP), Nomor Pokok Wajib Pajak (NPWP), dan Izin Usaha Industri , P-IRT NO telah dimiliki UD. ZAM. Dengan adanya perizinan sudah dianggap legal. Namun perlu dilengkapi sertifikat halal dan nomor dari Badan Pengawas Obat dan Makanan (BPOM).

b) Pengembangan Aspek Marketing dalam pemasaran produk cairan mengkudu selama ini ekspor ke Tiongkok. Perlu dikembangkang ke pasar dalam negri.

c) Pengembangan Aspek Produksi pada aspek kinerja produksi perlu adanya pengembangan pada bagian proses produksi, hal ini ditunjukkan proses produksi berwarna ilustrasi merah artinya tingkat kelayakan rendah. Maka perlu dikembangkan oleh UD. ZAM terutama pada bagian proses produksi adalah Standart Operasional Prosedure (SOP).

d) Pengembangan Aspek Sumber Daya Manusia Pengembangan pada tersebut terdapat kelebihan sistem gaji yang diberikan telah sesuai dengan upah minimum regional (UMR) dan angka pengangguran di pedesaan bisa berkurang. Namun kekurangan seperti organisasi dan job description, penjejangan karir belum ada karena usaha masih skala kecil, dan tingkat pendidikan karyawan relatif rendah < SMA karena semua pekerjaan sebagian besar hanya membutuhkan fisik, namun juga harus membutuhkan tenaga yang terampil dan berpendidikan.

e) Pengembangan Aspek Kinerja Lingkungan dapat disimpulkan bahwa UD. ZAM telah terbukti pada tingkat kelayakan tinggi, karena bahan baku mudah didapatkan.mudah untuk 
mendapatkan bahan baku dan produsen tunggal dalam usaha cairan buah mengkudu.

f) Pengembangan Aspek Keuangan berdasarkan output DSS UMKM, seperti asumsi tingkat bunga, break event point (BEP) kuantitas maupun penjualan, benefit coast ratio (BCR), payback period, net present value (NPV), probability index (PI), dan internal rate of return (IRR) sudah di asumsikan layak untuk di kembangkan.

\section{UCAPAN TERIMAKASIH}

Terimakasih kepada LPPM Universitas Muhammadiyah Jember yang telah memberikan dukungan sehingga penelitian berjalan dengan lancar.

\section{DAFTAR PUSTAKA}

Arikunto, Suharsimi. 2010. Prosedur Penelitian Suatu Pendekatan praktek. Jakarta: Rieneka Cipta.

Ariyanto, Ade Sofa, Deni Handani, Sasmito Prasojo. 2017. Analisis Ketersediaan Bahan Baku Terhadap Stabilitas Operasional Perusahaan (Studi pada PT. Sari Aditya Loka II Bungo). Jurnal Administrasi Sosial dan Humaniora (JASIORA) : Vol 2 No 2 HIm 1-13.

Badan Pusat Ststistika. 2018. Statistik Tanaman Biofarmaka. Jakarta Indonesia.

Bahari, Bima Fajar; Ahmad Dedy Syathori; Sri Hindarti. 2021. Analisis Kelayakan Investasi Ekspor Umbi Bunga Zephyranthes sp. (Studi Kasus: CV. Arjuna Flora, Kota Batu). Jurnal Sosial Ekonomi
Pertanian dan Agribisnis (SEAGRI) : Vol 9 No $1 \mathrm{HIm}$ 38-51.

Cholilie, Irvan Adhin. 2018. Analisis Kelayakan Finansial Agroindustri Bubuk Cincau Hitam (Mesona Palustris). Jurnal Teknologi dan Industri Pertanian Indonesia (JTIP): Vol 10 No 2 HIm 33-40.

Harisman, Kundang. 2017. Pola Kemitraan Antara Petani dengan PT. Indofood Fryto-Lay Makmur pada Usahatani Kentang Industri Varietas Atlantik (Studi Kasus di Desa Cigedug Kecamatan Cigedug Kabupaten Garut). Jurnal ISTEK : Vol 10 No $1 \mathrm{HIm}$ 102-116.

Haziz Sina, Gado Dramane, Philippe Tchekounou, Fidèle Assogba, KamirouChabi-Sika, Bawa Boya, Akim Soccohou, Adolphe Adjanohoun, Lamine Baba-Moussa. 2020. Phytochemical composition and in vitro biological activities of Morinda citrifolia fruit juice. Saudi Journal of Biological Sciences.

Heri Nurdiyanto dan Heryanita Meilia. 2016. Sistem Pendukung Keputusan Penentuan Prioritas Pengembangan Industri Kecil Dan Menengah Di Lampung Tengah Menggunakan Analitical Hierarchy Process (AHP). Seminar Nasional Teknologi Informasi dan Multimedia 2016. Yogyakarta.

Ibrahim, Jabal Tarik dan Ary Bakhtiar. 2017. Analisis Kelayakan Usaha Sari Buah Belimbing di Kota Blitar. JSEP: Vol 10 No 3 HIm 53-57.

Isnaeni Diniarti dan Sandi Iljanto. 2017. Strategi Peningkatan Daya Saing 
Andika Putra Setiawan, Pengembangan Usaha Agroindustri...

Industri Obat Tradisional (IOT). Jurnal Kebijakan Kesehatan Indonesia Vol. 06 Halaman 184 192.

Kementerian Perdagangan Republik Indonesia. 2020. Ekspor import obat herbal. Jakarta Indonesia.

Mahsa Motshakeri, Hasanah Mohd Ghazali. 2015. Nutritional, phytochemical and commercial quality of Noni fruit: a multibeneficial gift from nature. Trends in Food Science and Technology Volume 45, Issue 1, September 2015, Page 118 - 129.Faculty of Food Science \& Technology, Universiti Putra Malaysia, 43400 UPM, Serdang, Selangor, Malaysia.

Marimin, 2005. Teori dan Aplikasi Sistem Pakar dalam Teknologi Manajerial. Bogor.

Masyhud, Sulthon. 2011. Metode Penelitian Pendidikan. Jember: Lembaga Pengembangan Manajemen dan Profesi Kependidikan.

Otoritas Jasa Keuangan. 2021. Suku Bunga Dasar Kredit.

Rantung, Yulia; Sri Murni; Joubert B. Maramis. 2019. Pengaruh Kepemilikan Institusional, Market Share, Corporate Governance Terhadap Profitabilitas Perusahaan Manufaktur yang Terdaftar di Bursa Efek Indonesia Periode 2013-2017. Jurnal EMBA: Vol 7 No 3 HIm 2681-2690.

Sholihin, Rahmat; Suardi Tarumun; Didi Muwardi. 2016. Analisis Finansial
Usahatani Tanaman Hias Raphis Excelsa (Studi Kasus Kelompok Tani Labuai, Jalan Husada, Kecamatan Bukit Raya, Kota Pekanbaru). JOM FAPERTA Universitas Riau: Vol 3 No $1 \mathrm{HIm}$ 1-11.

Sogandi dan Rabima. 2019. Identifikasi Senyawa Aktif Ekstrak Buah Mengkudu (Morinda citrifolia L.) dan Potensinya sebagai Antioksidan. Jurnal Kimia Sains dan Aplikasi 22 (5) (2019): 206-212.

Sugiyono. 2010. Memahami Penelitian Kualitatif. Bandung: CV Alfabeta.

Sugiyono. 2013. Statistik Untuk Penelitian. Bandung:CV Alfabeta.World Health Organization. 2013. Book. Traditional Medicine Strategy 2014-2023. 